https://doi.org/10.18485/iipe_conv_conf.2021.ch8

\title{
IRAN'S ECONOMIC COOPERATION WITH EASTERN EUROPEAN COUNTRIES: EXTRAORDINARY SPACE FOR FOREIGN TRADE
}

\author{
Ali Beman Eghbali Zarchi ${ }^{1}$
}

\begin{abstract}
After the Soviet collapse in the late twentieth century, the Eastern European countries had to undergo profound political and economic reforms to qualify for entry into the European Union. While the political reforms have gone ahead slowly, in the economic area, these reforms have been on course to obtain international standards for producing industrial products. Considering the changes in the US and the possibility of a revival of the JCPOA nuclear agreement and the lifting of economic sanctions, there will be an opportunity for Iranian investors and the economic sector, which will provide more options for expanding economic relations. The Eastern European countries have a good market for our economic sector because these countries are culturally inclined to the east and are receptive to Asian and Eastern products, an advantage that Iran can invest in. The economic similarities (in production, market, and consumption) between Iran and the Eastern European countries and the Iranian economy's advantages and specifics in the region and world have led Iran to hold an important economictrade status for these countries. The Eastern European region has enjoyed fairly good industrial and technological capacity in the $20^{\text {th }}$ century, and its industries complement and overlap in many areas with Iran's heavy industries. Keywords: Foreign Trade, Economic Growth, East Europe, Competitiveness, Non-Oil and Engineering Services Exports.
\end{abstract}

\footnotetext{
${ }^{1}$ Senior Expert of European Studies. abeghbali@gmail.com
} 
In the present situation of the global economy, no single country is able to solely rely on its domestic resources and the resulting gains from its national economy to attain considerable growth in economic development. The growing trend of diversification of extraterritorial exchanges of goods and services, along with the fast flow of capital and the comprehensibility of fast technical and industrial growth, has led to the strengthening of the role of foreign trade in economic growth and the importance of boosting exports of goods and services to upgrade international economic cooperation. ${ }^{2}$ Nowadays, the export and import of goods and services have an influential supporting role in each country's domestic economy, and the more countries participate in international trade, the easier it will be for their respective development. Because foreign trade is the first step in increasing GDP, even when the import and export structures are different, it has a worthy role, and in the second step, considering the national value and international value of the exported goods, it can raise the income per capita. The amount of success in foreign trade has a direct relation to economic growth. ${ }^{3}$ Also, the resulting revenue from foreign trade and export of goods can be invested in the country's economic infrastructure and lead to an increase in public welfare. Also, the economic science intellectuals, while presenting various definitions of foreign trade, share common views on the following aspects: ${ }^{4}$

1. Foreign trade is a separate branch of the national economy, including trade operations as well as technical and scientific cooperation with the outside world. This includes the exchange of goods, warehousing, banking transactions, insurance, transportation, and even tourism.

2. Foreign trade shoulders two basic responsibilities in international trade operations and in international economic cooperation organizations.

Yet, international trade operations are a form of interdependence between producing units and the national economy in the area of the purchase and sale of goods and exports and imports, which are as follows: ${ }^{5}$

\footnotetext{
${ }^{2}$ Events and Analysis Bulletin No. 334 May 2020 P. 51- IPIS

${ }^{3}$ Events and Analysis Bulletin No. 334 May 2020 Page 57- IPIS

${ }^{4}$ Economic Diplomacy and Leading Opportunities (Vol. 1), Coordinator: Massoud Manshouri: University Scholars, 2020, p. 48

${ }^{5}$ Economic Diplomacy of the Islamic Republic of Iran: Trends and Developments, Opportunities and Challenges after the Nuclear Deal, Author: Morteza Damanpakojami pp. 33-57.
} 
A. International trade of goods, which includes the sale of produced goods by a country to other countries, and exports of all types of semimanufactured goods with limited value-added and total imports from a country done to secure producer needs and producing cycles,

B. International trade in commercial services, which are called intangible trade, includes operational services relying on imports and exports (transportation, insurance, trade licenses) and even international tourism,

C. Hybrid international trade based on re-exporting goods and, in some situations, importing semi-finished items and finishing them with specialised technical knowledge in order to achieve net value-added in exports,

D. International trade in the form of cooperation with regional, international, bilateral or multilateral economic organizations, in which process, each country's foreign trade is closely connected to the number of the strategic, organized and hybrid partners they have for exporting and importing of goods.

E. International trade is closely connected to how insightful the importers and exporters of goods are, and for successful international trade, governments are responsible for upgrading their exporters' understanding and knowledge of the governing global trade system,

F. Foreign commerce is a complicated and multi-faceted operation that is in compliance with the terms and conditions of the exporting and importing countries, international regulations, and even the 1980 Vienna convention regarding the international sale of commodities.

The reality is that Iran, with $1 \%$ of the world population and ranking first among the countries having oil and gas and being situated in the strategic regions of the Persian Gulf and Caspian Sea with direct access to a 500 million consumer market, has a tiny share in international trade, a share that is even more limited in electronic international trade, because the basic preconditions and prerequisites for developing electronic trade that will be mentioned below have not been met:

1. Building the necessary equipment and technical infrastructure

2. Legal framework and legal regulations

3. Effective, safe and proper mechanisms for electronic payments

4. Required tools for precise identification of the clients. 
Therefore, to increase our country's share and role in international trade, we must pay profound attention to this area. In his book, International Trade Operations, Dan Vesian, while pointing to the importance of electronic international trade, summarises its benefits as follows:

A: Effective and efficient information management

B: Optimal integration of suppliers of goods

C: Lowering the cost of exchanges

D: Lowering the cost of advertising

E: Optimal management of production, especially quantitatively

The reality is that the foreign trade sector of our country's economy in general, and non-oil exports in particular, is fundamentally underdeveloped and its symbols are tangible in exports of low-earning goods, a single-product economy, instability in the grand environment of the economy, and geographical concentration in our country's exports and imports partners. In the era of globalisation, the five areas of trade, financial markets, multi-national companies, world investment, and labour markets have had the most influence, the main reasons being the changes in production methods, the expansion of rationalism, the dynamism of investment, and technological innovation in communication and data-processing. In such a situation, competition will be more influenced by deep development in the organisation of production and economic exchanges in the third millennium, and although in the encyclopaedia of economics, the definition of competitiveness at the national and international levels is as hard and vague as the concepts of democracy, pluralism, and open economy, the competitiveness of each country lies in three main components: ${ }^{6}$

1. The economy's performance in the adaptation process with other countries

2. The country's status in the world trade

3. Each country's capability for optimal utilisation of its resources and capabilities. Also, the World Economic Forum defines each country's competitiveness as "hard and multi-dimensional" and deems this level

${ }^{6}$ Economic Diplomacy and Leading Opportunities (Vol. 1), Massoud Manshourip. 28 
of productivity in each country as the ability of the national economy to achieve sustained high rates of growth in GDP per capita, which is comprised of a set of institutions, policies, and factors that determine the rates of returns obtained by investments in an economy, comprising of 110 indexes, 12 pillars, and three sub-indexes. Of the 12 pillars, the four factors of institutions, infrastructures, grand stability of the economy, hygiene, and basic education are basic requirements, and the six factors of training and education, efficiency, labour market, labour market efficiency, efficiency of goods market, advanced financial markets, technological readiness, and the size of the market are boosters of efficiency, and the two factors of progress in business and innovation are other pillars of technological complexities. There is no doubt that if we see the WTO as the result of interaction and connection between the relative supply and demand of various countries aimed at gaining profits and value-adding through upgrading capacity and diversification of production, we will more than ever understand the important role that development of exports plays under the oppressive western sanctions imposed on the Islamic Republic of Iran, and we will come to understand the goals of implementing the mechanisms of the Resistance Economy. This is why, under the existing situation and according to the latest assessments made by the World Economic Forum, our country, which ranks $18^{\text {th }}$ in the size of the market, and $25^{\text {th }}$ in access to foreign markets among 139 countries, has no acceptable stand and its indicators are evident in the statistics below. ${ }^{7}$

- $45^{\text {th }}$ in economic stability

- $82^{\text {nd }}$ in institutions

- $74^{\text {th }}$ in infrastructure

- $96^{\text {th }}$ in readiness to attract technology

- $135^{\text {th }}$ in efficiency of the labour market

- $98^{\text {th }}$ in efficiency of the financial market

- $35^{\text {th }}$ in communications

- $91^{\text {st }}$ in the process of Business Progress

${ }^{7}$ Fundamentals of Economics: Microeconomics, Macroeconomics, Tahmasb Mohtasham Dolatshahi p. 129. 
- $15^{\text {th }}$ in controlling international distribution

- $87^{\text {th }}$ in vocational and higher education

- $66^{\text {th }}$ in innovation

- $120^{\text {th }}$ in developed financial market

- $54^{\text {th }}$ in hygiene and basic education

With regard to the statistics and figures presented and the general policies of the Resistance Economy, in paragraph two, the primacy of the knowledgebased economy, the organisation of the national system of innovation for upgrading the global status of the country and increasing the share of production and export of products and knowledge-based services and accessing the first rank in the region, and in paragraph 10 , the importance of fully target-purposed support of exports of goods and services, in proportion with the value added and with a positive net currency balance, expanding foreign trade services and transit, encouraging foreign investment in exports, planning national production fitting to the exports needs, and shaping new markets and diversifying the economic bonds with various countries, especially the regional countries, and sustained raising of our country's share in the target markets has been stressed. Taking basic steps to fill the deep gap with the developed and industrialised countries is necessary, and in doing so, we have to shed off certain traits and gain some others, which are summarised in the following two pivots:

\section{A: Preventive Traits:}

Preferring personal interests over collective and national interests, consumerism and overspending, insensitivity to production costs, low productivity and efficiency, lack of camaraderie and cooperation among groups and organizations, conservatism, not valuing time, inattention to quality and standards, lack of a grand long-term look at the markets, lack of efforts to precisely comprehend the markets and the consumer's tastes, lack of the necessary technological and communication infrastructures.

\section{B: Required Traits:}

Motivation, successes, seeing work as a value, teamwork, regularity, competitiveness, productivity, innovation, and attention to technology, research and development, transfer of technology, quality and standards, the environment, national production, law-abidingness, and futurism, full 
comprehension of the importance of exports, and promotion of the country's share in international trade. ${ }^{8}$

This group of traits has been many times stressed in the 20 Year Vision of Development and the Resistance Economy policies. Also, in studying the ways trade expands alongside the type of foreign policy towards other countries in the bilateral, multilateral, regional, and international areas, the three following pivots are of paramount importance:

1. The international economic and trade organisations (UNCTAD, the World Economic Forum, and the World Bank)

2. Multinational Companies

3. Globalisation, especially in the international economy;

Among these three pivots, as Dolatshahi writes, globalization, meaning the realisation of labour division, has had a more prominent role on the international level and economically includes the following dimensions: ${ }^{9}$

- International Integration of the Labour Market and the Capital Market

- Removing Trade Barriers

- Production of Goods by Multinational Companies

- Integration of Fiscal and Monetary Markets on an International Level

- Expansion of Information across Borders

The Iranian economy's advantages are generally as follows: geo-economic status, higher economic ranking in the world, young and educated population, existence of rich mineral and natural resources, robust economic infrastructures, variety in the economic sectors, and richness in oil and hydrocarbon resources ${ }^{10}$, being the world's fourth oil producing country, having the world's second major gas reservoirs, tourism and eco-tourism industry, production of aluminium and cobalt, global high rank in aluminium,

\footnotetext{
${ }^{8}$ Economic Diplomacy and Leading Opportunities (Vol. 1), Massoud Manshouri, p. 118

${ }^{9}$ Fundamentals of Economics: Microeconomics, Macroeconomics, Tahmasb Mohtasham Dolatshahi p. 79.

${ }^{10}$ Director of Exploration of the National Iranian Oil Company: With the new discoveries, Iran's position as the largest holder of oil and gas resources in the world has been established, and our authority in this rank will be maintained. (https://www.iribnews.ir/ $\mathrm{fa} /$ news/2547505
} 
manganese, and copper reservoirs, and having a worthy rank in the world for diversity in agricultural products. These characteristics have led Eastern European countries to be interested in investing in exporting their products to Iran. For example, the countries of Slovenia, Latvia, the Czech Republic, Bulgaria, Croatia, and other countries can invest in the electronic and engineering industries, furniture, food, chemical industries, railways, drugs, water, car parts production, hydro-electricity, technologies for the environment, building and civic plans, tourism, land and sea transportation, electric machinery, and other areas in Iran.

On the other hand, East European industrial production complies with European standards, and these countries are hubs for producing drugs, agricultural mechanisation industries, medical and dental equipment, and railway industries. In particular, in Romania, the pharmaceutical industry has considerably advanced and follows the highest European and American standards. Also, the fixed prices of food and industrial products in these countries are lower than in Central Europe. By this token, Iran can invest in the areas of building roads, hotels, manufacturing agricultural machinery, gemstones, coal, agricultural products (dried foods and fruits, nuts, spices, and fresh fruit), building, building materials, electricity projects, water supply, petro-chemistry, car manufacturing, food industries, dam building projects, subway projects, tunnels, building silos, creating irrigation and piping networks, energy (building power plants), carpets, furniture, textiles, car oil, petrochemical products, and other areas in these countries and export engineering and technical services to them. In the view of Eastern European countries, including Romania, the Czech Republic, Slovakia, Austria, Moldavia, and some other Schengen non-members, Iran should be looking for the target markets in these countries in its relations with Europe because these countries, with regard to the conditions and positions that hold, can be receptive to Iranian products. ${ }^{11}$ Of course, one of the requirements for consolidating presence in Eastern European markets is the production of agricultural and industrial products in accordance with European standards, which fortunately, Iranian products comply with, resulting in Iranian products' having acceptable European standards and Iran having the requirements to

\footnotetext{
${ }^{11}$ Political Geography of Europe Authors: Mohammad Mehdi Mazaheri, Azam Mollai, Majid Kafinasher: Islamic Azad University (Khorasgan), 2018, P. 79
} 
export its industrial products to Europe. But unfortunately, in the past years, the Iranian economy has not paid attention to the Eastern markets of the green continent, and Iran's trade has been focused solely on some Central European countries such as Germany, France, and Spain. ${ }^{12}$ Furthermore, nowadays, this region's countries have turned into hubs for producing drugs, agricultural mechanisation industries, medical and dental equipment, railways industries, primary chemical materials and licenced additives, fertilizers, seeds, chemical agricultural pesticides, steel and precious metals industries, cosmetics and hygiene primary materials, and in particular, in Romania and Austria, the pharmaceutical industries have considerably advanced and comply with the highest European and American standards. For this, their products are exported to Europe, North, and Central America. All industrial, as well as agricultural and livestock products, meet European standards in Slovakia, the Czech Republic, and Moldavia. Therefore, with a high degree of certainty, the consumer markets can be receptive to these products.

Iran and Romania's interactions are old and traditional, so the first and last Romanian presidents who visited Iran did so during the waning decades of communism. ${ }^{13}$ An excerpt of the talks exchanged between the Shah of Iran and Ceausescu has been quoted by one of the Shah's associates: "Pahlavi believed that small countries could not stand on their feet without their bigger friends, but Ceausescu said it was the big countries that could not survive without plundering small countries." Also, Ceausescu, at his meeting with the Shah of Iran, told him: "Iran and the oil-rich Middle East countries must form a strong alliance and extract their oil freely and sell it by themselves." Ceausescu added: "Romania, until before the Second World War, was an oil exporting country to Europe, but the looting companies sacked its oil to the last barrel and left behind a desolate environment. ${ }^{14}$ The westerners buy your oil, but in return give you so little money that you can only import necessary oil-rigging equipment and pay for the technical equipment and other requirements needed for oil wells, and a tiny amount is left for you to buy food in order for you not to starve and to be able to extract oil and give it to

\footnotetext{
12 Events and Analysis Bulletin No. 326 Aug. 2019 P. 44- IPIS

${ }^{13}$ Romanian Foreign Policy and Diplomacy Volume 2 Academy of Sciences P. 157

${ }^{14}$ http://www.tarikhirani.ir.fa A review of Iran and Romanian Relation in Ceausescu eraHoseine sokhanvar
} 
the westerners." The Romanian leader depicted the western companies as ruthless looters that plundered the third world countries' oil and minerals and, in return, would pay little money as charity, money that was enough only to pay for the extraction operations, but the Shah believed: "This man is crazy. He spends more of his time on propaganda against the west than on bilateral negotiations." The important fact was that Ceausescu's visit to auto factories was a staple of his plans in Tehran. On his second trip, during Rafsanjani's presidency, he again visited the Iran Khodro auto factory. ${ }^{15}$

It is no secret that Romania has a large complementary capacity for foreign trade with our country, and this country's foreign minister, in his 2016 trip to Tehran and after negotiations with Tayebnia, the Iranian Minister for Financial and Economic Affairs, talked about a \$3 billion ceiling for economic exchanges between Iran and Romania and added, "we should make the most out of the new economic and political conditions that have unfolded in Iran's international relations with the world." Also, to the economic activists, Poland is a great market which is receptive to Iranian goods because this country's economic policies are based on barter of goods, and also, in the postsanctions era, it is a unique market for Iran. It seems that Poland has a \$40 billion market open to the Iranian economy in the post-sanctions era, and our country can, by proper targeting, on the one hand, and producing agricultural and industrial products according to EU standards, on the other hand, expand its area of economic exchanges and give a new lifeline to its national economy through these exchanges.

The Eastern Europe region includes the Balkans, consisting of over 10 countries, all either having become EU members (like Slovenia, in 2004) or waiting in line for membership in this political and economic establishment (like the Republic of Serbia). In any case, Iran has long had a special place in the Balkans as, historically, some nations of this region see themselves as of the Iranian race (like the Croats), and the Persian language has had much attraction to the intellectuals and literary figures of the Balkans in the past, and some poets and mystics have composed their poetry in Persian. Over the last 6 decades, Iran has had considerable industrial cooperation with Eastern European countries, which had been considerable until the collapse of communism, especially Iran's post-revolutionary era relations, in order of

${ }^{15}$ The Last dine of Ceausescu, Alibeman Eghbali Zarch, P. 39 
importance, with Bucharest, Belgrade, Prague, Budapest, and Warsaw. During the Pahlavi era, the volume of exchanges between Iran and these countries was between $\$ 50$ million and $\$ 300$ million (Romania $\$ 300$ million, Czechoslovakia \$100 million, former Yugoslavia \$70 million, Poland \$50 million, and Hungary $\$ 40$ million). During that time, Iran traded with Romania in the electric and agricultural machinery industries, with the former Czechoslovakia in power plant construction, aluminium production, and Tabriz Machine Manufacturing with Poland in ship building and copper, with Hungary in agriculture and the environment, and with the former Yugoslavia in heavy industries. After the Islamic revolution, the volume of exchanges with these countries has considerably increased, so that only the volume of exchanges with Romania was over $\$ 1$ billion in 1988. Energy is one of the important factors for cooperation in this region. According to many experts, in recent years, Iran has not paid attention to Eastern European markets and Iran's trade has been focused on some Central European countries like Germany, France, and Spain. But in the new conditions and in a situation where Eastern Europe is distancing itself from Central European economic policies, it is the best time for Iran to think about these countries' markets and step up the exchanges. ${ }^{16}$

Among the issues that impede presence in Eastern European markets are improper concessions, facilities, rampant bureaucracy, and legal and institutional issues. The question is whether Iran's diplomacy apparatus is able to get over these thorny economic and trade problems with East Europe.

Below we will enumerate the most important economic indexes and the volume of foreign trade exchanges, imports, and exports with these countries: ${ }^{17}$

\footnotetext{
${ }^{16}$ Events and Analysis Bulletin No. 326 Aug. 2019 P. 61- IPIS

${ }^{17}$ https://economic.mfa.gov.ir/portal/newsagencyshow
} 


\begin{tabular}{|c|c|c|c|c|c|}
\hline Row & Country & $\begin{array}{l}\text { Population } \\
\text { (million) }\end{array}$ & GDP US dollar & $\begin{array}{c}\text { GDP } \\
\text { Per Capita }\end{array}$ & $\begin{array}{c}\text { GDP Growth } \\
\text { Percent }\end{array}$ \\
\hline 1 & Slovakia & 5 & 160 & 29,000 & 4 \\
\hline 2 & Slovenia & 2.2 & 48 & 34,000 & 5 \\
\hline 3 & Albania & 3 & 16 & 5,500 & 4 \\
\hline 4 & Bulgaria & 7 & 55 & 7,800 & 3 \\
\hline 5 & Bosnia & 3 & 20 & 5,700 & 2 \\
\hline 6 & Czech & 11 & 368 & 30,000 & 5 \\
\hline 7 & Romania & 21 & 239 & 12,000 & 4 \\
\hline 8 & Serbia & 8 & 106 & 14,000 & 3 \\
\hline 9 & Croatia & 4 & 61 & 15,000 & 3 \\
\hline 10 & Poland & 38 & 610 & 31,000 & 3 \\
\hline 11 & Hungary & 10 & 290 & 29,000 & 4 \\
\hline 12 & $\begin{array}{l}\text { Northern } \\
\text { Macedonia }\end{array}$ & 3 & 10 & 5,000 & 4 \\
\hline 13 & Montenegro & 0.6 & 11 & 18,000 & 5 \\
\hline $13^{*}$ & Kosovo & 2 & 8 & 4,000 & 4 \\
\hline Total & 117.8 & 1192 & & & \\
\hline
\end{tabular}

The Islamic Republic of Iran does not recognize Kosovo

\begin{tabular}{|c|l|c|c|c|c|c|}
\hline Row & \multicolumn{1}{|c|}{ Country } & Exports & Imports & $\begin{array}{c}\text { Mutual } \\
\text { exchanges }\end{array}$ & $\begin{array}{c}\text { Iranian } \\
\text { exports }\end{array}$ & $\begin{array}{c}\text { Iranian } \\
\text { Imports }\end{array}$ \\
\hline 1 & Slovakia & 73 & 71 & 60 & 28 & 32 \\
\hline 2 & Slovenia & 28 & 27 & 51 & 3 & 48 \\
\hline 3 & Albania & 3 & 6 & 5 & 5 & \\
\hline 4 & Bulgaria & 29 & 33 & 76 & 32 & 42 \\
\hline 5 & Bosnia & 6 & 10 & 77.5 & 76 & 1.5 \\
\hline 6 & Czech & 180 & 160 & 92 & 16 & 76 \\
\hline 7 & Romania & 67 & 83 & 115 & 45 & 70 \\
\hline
\end{tabular}




\begin{tabular}{|c|l|c|c|c|c|c|}
\hline Row & \multicolumn{1}{|c|}{ Country } & Exports & Imports & $\begin{array}{c}\text { Mutual } \\
\text { exchanges }\end{array}$ & $\begin{array}{c}\text { Iranian } \\
\text { exports }\end{array}$ & $\begin{array}{c}\text { Iranian } \\
\text { Imports }\end{array}$ \\
\hline 8 & Serbia & 15 & 20 & 20 & 12 & 8 \\
\hline 9 & Croatia & 34 & 33 & 8 & 4 & 4 \\
\hline 10 & Poland & 200 & 202 & 225 & 90 & 135 \\
\hline 11 & Hungary & 124 & 117 & 35 & 10 & 25 \\
\hline 12 & $\begin{array}{l}\text { Northern } \\
\text { Macedonia }\end{array}$ & 6 & 5 & 6 & 5 & 1 \\
\hline 13 & Montenegro & 3 & 3 & 150 & & \\
\hline $13 *$ & Kosovo & & & & & 436 \\
\hline Total & & 763 & 770 & 763.6 & 327 & 4 \\
\hline
\end{tabular}

Exports and Imports in Billion Dollars

Mutual Exchanges is in million dollars

In addition to Romania and Poland, other countries in the region also have the capacity to cooperate with our country. For example, Slovakia is another member of the EU that, after the JCPOA nuclear deal, declared readiness to broaden ties with Tehran, and a number of its officials visited Iran in February 2017 to upgrade their relations with Tehran to the desired level. ${ }^{18}$ There is a lot of potential for the two countries' ties to be revived, especially in the auto industry, energy, banking, petro-chemistry, and mining, which can be turned into joint investment, increased production, and a better economy for the two countries if economic activists and officials work hard enough. Also, the Iranian economic activists believe that Croatia is an important country for them, and this importance is not merely due to its geo-political status, but because Croatia, as a friendly country that has never left Iran alone, has many advantages over other countries. On her trip to Iran four years ago, after the Iranian president's trip to Croatia 12 years ago, which was a turning point in bilateral relations, Kitarovic and the Iranian side stressed the importance of broadening ties and cooperation in all areas, especially in energy. The important thing is that there are huge capacities in various areas, including the knowledge-based economy, transfer of technology, petrochemical

${ }^{18}$ https://economic.mfa.gov.ir/portal/newsagencyshow 
industries, reviving banking and financial relations, mines, steel industries, and energy for Zagreb and Tehran in the post-sanctions era. Although, due to western sanctions, the trade exchanges between the two countries have decreased, according to the experts, considering the Croatian capacities and capabilities, the two sides can jointly invest in the areas of tourism, oil and gas excavation and production, petrochemical industries, production of drugs, manufacturing locomotives, and building ships. In Slovakia, the Czech Republic, and Moldavia, too, all industrial, agricultural, and livestock products are of European standards. Therefore, the consumer markets can be, with certainty of quality, receptive to these products. Also, the fixed prices of food and industrial products in this country are lower than those in Central Europe. Therefore, Iran can invest in the areas of building roads, hotels, manufacturing agricultural machinery, gemstones, coal, agricultural products (dried foods and fruits, nuts, spices, and fresh fruit), building, building materials, electricity projects, water supply, petro-chemistry, car manufacturing, food industries, dam building projects, subway projects, tunnels, building silos, creating irrigation and piping networks, energy (building power plants), carpets, furniture, textiles, car oil, petrochemical products, and other areas in these countries and export engineering and technical services to them.

\section{CONCLUSION}

The Eastern European region is strategically important and has always been a flashpoint for the start of conflicts and a hotspot for hard and soft rivalry among great powers. Many believe that dominating this region is a kingmaking factor in the rise of big global powers. From the perspective of sea geopolitical importance, this region has access to the Mediterranean and the Black Sea for global transportation of energy. Also, from a geopolitical standpoint, the region has been the root of many crucial developments. No doubt, this region's countries, which today include about 14 countries, of which 8 are EU member states, due to historical events and Iran's multidimensional presence, have more cultural commonalities with Iran than western countries of the continent, in an adaptation process. ${ }^{19}$ Iran's relations with this region's countries have considerable and important cultural and economic impacts, in

${ }^{19}$ Events and Analysis Bulletin No. 326 Aug. 2019 Page 44- IPIS 
a way that, on one hand, in the cultural area, many of the great and unique figures of the shining Iranian culture and civilization, and noble Persian literary works like the poems of Saadi, Hafiz, Firdausi, Khayyam, and others are well known, and on the other hand, in many of these countries, Iran is known for its commodities such as carpets, pistachios, caviar, and oil.

Considering widespread global efforts made to achieve a maximum share in the global markets, the Islamic Republic of Iran's special status in the international arena and its process of growth and development, despite enjoying huge human capital and God-given natural resources, will not reach a stable stage without profound development in the 12 pillars of competitiveness of the economy and trade and a change in the general view of governmental and private institutions and organisations. In addition, our country's commercial diplomacy must, in proportion to the increase in capabilities and capacities for exports, add to its vigour and dynamism, and pay special attention to training and employing commercial advisors who can, according to scientific standards (at least 6\% increase in trade per each advisor), play a worthy role. However, in a situation where each day competition in trade and the economy becomes tense and the big powers try by the utilisation of economic tools, especially oppressive sanctions, to exert more international pressure, there is no doubt that the solution to achieving welfare and economic dynamism is a change of view and approach toward the institutions, structures, and the main pillars of production and international trade, along with inspiration from the basics of the Resistance Economy and an influential translation of the God-given capacities and our country's huge human capital.

\section{BIBLIOGRAPHY}

Damanpakojami Morteza, Economic Diplomacy of the Islamic Republic of Iran: Trends and Developments, Opportunities and Challenges after the Nuclear Deal, Author: Publisher: Ministry of Foreign Affairs, Tehran 2018,

Eghbali Zarch, Alibeman, The Last dine of Ceausescu, University Scholars Publications, Tehran, 2020

Manshouri Massoud, Economic Diplomacy and Leading Opportunities (Vol. 1),: University Scholars,Tehran 2020 
Mazaheri Mohammad Mehdi, Mollai Azam, Kafinasher Majid, Political Geography of Europe,Islamic Azad University, Khorasgan, 2018

Mohtasham Dolatshahi Tahmasb Fundamentals of Economics: Microeconomics, Macroeconomics, pub. Khojasteh, Tehran, 2014

Academy of Sciences Publications, Bucharest, 2018, Romanian Foreign Policy and Diplomacy Volume 2

Events and Analysis Bulletin No. 326 Aug. 2019, No. 334 May 2020 -No. 344 Feb. 2021, IPIS

https://economic.mfa.gov.ir/portal/newsagencyshow

http://www.tarikhirani.ir.fa A review of Iran and Romanian Relation in Ceausescu era- Hoseine sokhanvar 